$616.155 .244: 611-018.46: 578.085 .23$

骨䯣組織培盖法による骨髄巨核球に関する研究

\author{
第 1 編 \\ 人.並びに海漠骨艏巨核球の種々なる退行性変化について \\ 岡山大学医学部平木内科教室（主任：巫木 潔教授） \\ 副手。大河原 健 次 郎
}

[昭和 34 年 7 月 14 日受稿]

$\begin{array}{cl}\text { 第 } 1 \text { 章 } & \text { 緒 言 } \\ \text { 第 } 2 \text { 章 } & \text { 実験材料並びに方法 } \\ \text { 第1 } 1 \text { 節 } & \text { 実験材料 } \\ \text { 第 } 2 \text { 節 } & \text { 実験方法 } \\ 1 . & \text { 培養方法 } \\ 2 . & \text { 観察方法 } \\ \text { 第3 章 } & \text { 実験成績 }\end{array}$

第1章 腥言

血液細胞の形態学的変化江関する研究, 就中体外 に取出した血液細胞の退行性変化に就いては， 1892 年 Maragliano83) 牲生活力を失つた白血球の形態学 的変化並び染色状態の変化を研究して以来, 白血 球に関しては染色標本や暗視野標本下における Boden ${ }^{51)}$, Philipsborn90), Barta48), Naegeli88), 小 坂17)，片山13)，平凧等29330）の研究，更に最近では 位相碩微鏡を用いての Bessis60)，Kosenow73）等の 業綪があり，又赤血球化就いても Kawalewski72) が体外保存赤血球の退行性变化に就いて記述して以 来, 各種物理化学的条件, 薬物或は放射線の影響等 について種なの研究かなされ，本邦においても水 川37), 右馬39の系統的な研究がみられる.

酸つて骨䯣巨核球の退行性変化に関しては，唯各 種突患者就中特発性栓球減少性紫病患者にみられ る病的巨校球像について記載されていると過ぎない。

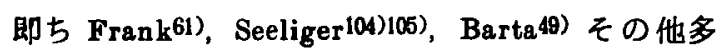
くの研究者により報告がなされて来たか，これらは 主として塑抹染色標本乃至は固定切片標本による変 性像の锤察であり，しかもその所見は極めて断片的 且区ヶである。

一方動態㓋察により骨随巨核球の形態学的観察を
次
第 1 節 骨髄巨校球の胞体の退行性変化につ いて
第 2 節，骨䯣巨核球の校の退行性变化につ いて

第 4 章 総括並びに考案

第 5 章 結 椧

行つた者には, Wright113)，前原36)，位田4), Rich94), 栗原15)16）そして滰川24）等がいるが，いずれもそ の退行性变化の研究に迄は及ばず, 新鮮標本による 変性像の報告は，1948年位相差影微镜が血液学の分 野に導入されて以来の事であるとて云つあ過言でな い. 従つて骨髄巨核球の退行性変化の観察も。 Bessi850)，Dameshek92)，Izak ${ }^{69)}$ 等少数の研究者侣 みられるに過ぎず，しかむ退行性変化そのあのに関 する系統的な研究に至つては未だ全くその報告をみ ない.

私は乎木内科教室考案骨髄簡易組織培養法に依り， 位相差顕锳鏡を用いて，培養下の骨髄巨核球の各種 変性像に就いて，詳細な形態学的観察並びに分類を 試みたのでとこにその成績を報告する．

\section{第 2 章 実䀦材料並ひに実験方法}

第 1 節 実酫材料

人の場合は，健康人の胸骨穿刺により得られた贯 髄組織片を用いた。胃稙穿制液は直ちに隇菌リンゲ ル氏液中に移し，液中の具檤組織片に血液が凝固附 着するのを防ぎ，再び新しいリンゲル氏液中に甾随 組織片のみ取出して洗つた，海㩧の場合は，体重 250 350 g の比較的若い健尿海犋の大腿骨骨髄を 用いた，海犋を撲殺後直ちに大腿胃を取出し，筋肉 
及び腱を除き，ヨードチンキで消毒した後，骨割り にて骨質を研き，骨䯣を無菌的に取出して滅菌リン ゲル氏夜中で珗つた。 とれらの骨髄組織片は, 眼科 用グレェーフェ氏刀にて約 $1 \mathrm{~mm}^{3}$ の小片とし，て れを培養組織とした。

培地支持体としては，健康人並びに同一海犋の血 清を使用した。

発有促進物蜇としては V. B12 1 cc 中 $100 \mathrm{r}$ 含有 注射液（以下単に V. $B_{12}$ 液と称す）を用いた。

\section{第 2 節 実験方法}

1. 塔養方法

平木内科考案簡易骨稙組織培暬法（以下簡易法之 称す）を用いた．即ち予め土手（高さ $200 \mu$ ) を作 つた良質载物硝子の中央に $1 / 4$ 注射針にて血清 1 滴 を滴下し，硝子棒を用いて直経約 $15 \mathrm{~mm}$ の円形に 拡げ，その中央部に前記骨噵組織片を 1 個求き，次 いでその上に同大の注射針で V. $\mathrm{B}_{12}$ 液を 1 滴添加 する，次に被覆硝子を土手の上に渡し，パラフィン で封入した後, $37^{\circ} \mathrm{C}$ の䁔卵器中に被覆硝子面を下 にして入れ，以後遂時的に取り出し，保温箱中にて 鏡検した.

\section{2. 観察方法}

観察は位相差预微鏡に依り，顕微鏡加温装置を用 いて行なつた，位相差顕微鏡は日本光学製可変位相 差顕微鏡の BM，DM 及び DLL，或はオリンパス 光学整スライド型可変位相差頙溦鏡の NM，PM を 使用し，倍率は $600 \times$ 乃至 $1000 \times$ 亿て尃 ら非殴挫 観察による動態観察を主とし, 補助的に圧挫を行い 観察結果を検討した。鹳察温度は原則として $37^{\circ} \mathrm{C}$ とし，必要に忘じ高温或は低温に暴して細胞变性の 推移を追求した。尚, 種々なる退行性変化を追求す る目的で，薬物の直接渿加や機械的制韩を与えてそ の影嬕をみた。

\section{第3章実 酫 成 精}

第 1 節 骨髄巨核球の胞体の退行性变化に วいて

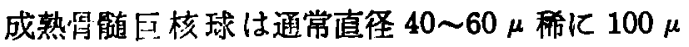
に達する巨大な細胞である，健常な巨核球の胞体は 略々均等な微練乃至稍々粗大な固有顆粒にて涨漫性 且稠密に充たされ，個々の顆柆の屈光性は余り著明 でない，胞体内・外野の区別は大多数のものでは明 瞭でなかつたが，時に明らかに内外二層を認めるる のもあつた，加るあのでは，外層に比し内層の顆 粒は比较的粗大であつた。尚，屡々核を中心として
同心性に顆柆の首状配列を見たが，顆粒の配列その 他において，静止時の巨核球之運動時の巨核球との 間汇有意の差を見出だせなかつた，又健常巨核球の 胞体は全体として充実感を示し, 胞体縁は培地之鋭 利に境せられ，光輝性の強い量輸により取囲まれて いる.

巨核球の胞体は，以下述へるが如き退行性変化の 過程において，上述の健常な状態から著しい変容を 遂げて，ついには崩壊消喴にまで至るのである。そ の変性像付，培地条件その他にて各種の様相を呈し， しかむてれらが互に錯綜している為, 特定の変性像 として取出す事は可成り困難であるが，ここでは主 たる変化を基として次の如き分類を試みた。

\section{1. 顆粒異常}

骨髄巨核球において屡々認められる初期变性像の 一つである．即ち培養経過につれて，固有顆粒は渐 次粗大化し，大小不同性を示す様になり，同時㙞顆 粒の光輝性も次第に増してきた，又一方では顆粒の 集合傾向を示すむのあみられる様になつた，かかる 変化の為，胞体は一見平滑さを失い，表面に多数の 小さな凹凸起伏を形成しているが如く観察された。 かかる顆柆の変化に引続き, 或は平行して他の退行 性変化が起る場合もあるが，又そのまま後述の粗糙 変性汇移行し崩買するものも多く見られた。

\section{2. 分泌顆粒形成}

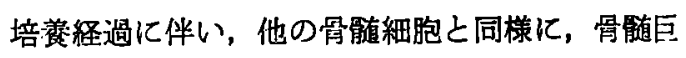
核球にも屡々分泌顆粒の出現を認めた。乙れは最初 は微細球状顆粒として現われ，次第にこの大きさを 增すにつれて，その顆粒の中心部は青白色の特有な 光沢を有し, 中心より周辺泊向つて次第に同心性に 屈光性を減し，周辺部にて暗黑色輪を形成する特異 な小顆粒えと成長し，大きさ直径 $1 \sim 2 \mu$ 位のむの が多いが, 稀には 3 4 $\mu$ にも達するすのも見られ た. 又数も数個のあのもあれば数十個に及ふらのあ あつて不定であつた，功る分泌顆粒は胞体内部に も認める事があるが，一般に細胞表面任近く存在す るもので，或は散在性に，或は集団乃至列状をなし

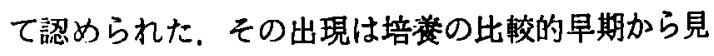
られ，就中被覆硝子面に附着せるものにおいては， 培美数洔間後には既に出現を認めた。培旁経過とと もに数や大きさを増してくるものが多いか，退行性 変化が高度になると, 反つて消隇乃至は培地中に遊 離した。

尚，分泌顆粒の存在する巨核球においても，運動 能を有する事を展々認めた。 
又分泌顆柆の出現頻度は人に比し海㩧骨能有巨核球 において遥かに高率であつた。

\section{3. 空胞形成}

最も普通に見られる退行性変化である。乙の空胞 の出来方には二種類ある．その一つは胞体内部に小 空隙として発生するむので，最初は辺緑不明膫な薄 暗黑色の球状物に見えるか，次第に辺緑も朋嘹とな り，周团の培地上り可成り明るい半透明の類球状物 として認められるに至り，遂には胞体全体が大小の 空胞で占められてしまう。数は 1 個より10個以上に 及ぶ事があり，大なるるのは 10 15 $\mu$ 以上に達す るむのがあつた。他の一つは胞体表面に略々同大の 空胞を一時に多数発生するもので，てれは增大する に従つて篻接空胞と融合し, 次第に大空胞を形成し て行くあのである. かかる空胞内は通常笽構造であ るが，時に微細な既末浮游を認めた，多数の空胞を 形成した巨核球では，空胞間に残存する胞体は著し く光輝性を增して，個くの固有顆粓を識別し難くな るが，胞体緑は一般に明膫に認められた。一方核は 通常その存在を認めろ事が出来なかつた。

尚胞体より巨大な空胞が培地中に向つて突出せる 状況を屡々見たが，かかる空胞像は平渭で光煇性の 強い，比較的厚い胞体膜をもつて培地と境せられて いた。

又比較的稀であるが，核の周囲に限局して小空胞 の発生を認める事があつた。

4. 水泡形成

水泡は培地よりも屈光性が稍々弱く，非常に薄い 一層の膜で境せられた，透明な球状乃至は半球状の 胿出物として観察せられた。

水泡を大別して, 胞体縁の一部自由縁に限局して 丸く膨出する局在型, 胞体全表面より多数の小水泡 を発生する多発型，更に大水泡を形成して次策に胞 体全体を覆うに至る挴漫型とに分つ事が出来た。

局在型の出現時期は，一般に巨核球の退行性変化 が余り進行していない時期に見られるのが普通であ つたがそその出現は比校的桸であつた。

多発型は巨核球の胞体の高度の荒廃により粗精之 なつた核球に稀に見られたが，蒸溜水を培地中に 添加した際，核流出後の残存胞体より陸続として小 水泡の発生を認める事があつた。

洒漫型は最む屡々見られる変性像の一つであつた。 出現時期は一般に胞体崩壊前段階において見られた か，胞体内容物，例えば顆粒や胞体破碎片等が水泡 内に移行して盛んにブラウン遇動を営んでいるるの
あ尿々認められた。

5. 球状膨出

巨核球退行性变化の稍々進んだ時期に見られる現 象で比较的上く遭遇した．胞体縁の一部が突然球状 に膨出し，短時間の間に急速にその容皘を增し，時 には殆ど胞体主部之同大位任迄跀出する。 この際胞 体主部においては顆粓の帯状の流れを認め，膨出部 に向う縦滴状の細長い紋理を呈した。 又核も㞗々練 長くなつて移動するのを認めた．膨出部は胞体主部 とは明らかに槥造を巽にするむので，非常に微細な 顆粒にて湾漫性に充たされ，主部との境は明嘹な一 線て劃されていた．核がー一部樹出部に移行し，主部 との境界部において絞把瞆頓せられている像をみる 事ちあつた，かかろ臆出部は桸に再び胞体内に吸収 せられてしまう事もあるが，多くの場合非可逆的で あつた。尚，稀に核のみ笑出する事があつた。

\section{6. 小舌状突起形成}

退行性変化が進み，榙も明膫化して来た巨核球に おいて，突然胞体に恰も身震いする様な摇振りが起 ると同時に，胞体全縁から多数の然構造不透明で光 輝性の稍々そしい3 5 $\mu$ 位の, 時には $10 \mu$ 以 上にも達する小毛状突起を出すすので，乙の為胞体 は管縮状となり，胞体辺縁は平骨さを失つて変形し 不整となる，乙の突起は出沒自在で，且つ個々の突 起は時々刻々変容して大きさや長さを変えて行くが， 出現後早い時には数秒乃至十数秒後に再び胞体内に 吸収せられて，胞体が原形に復するのを認めた，併 し間もなく再び同様の現象が反復されるのが見られ た，氻る突起は低張培地中では急速に膨大して水 泡化してしまうが，等張培地中では或程度可逆性を 示した。

この小舌状突起形成は, 培地蒸溜水, 苛性了ル カリ，壏酸等の直接添加㭙にも認力られたが，培液 の振鳁や巨核球自体を压迫する事によつても容易に 発生した。

\section{7. 泡抹形成}

小舌状突起より引続き，或は企くこれと無関係に 胞体表面において認められた。 これは小舌状突起と

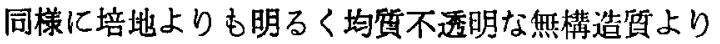
なり，胞体表面を被つて半球状乃至は波状㬿隆等の 変容運動を活泳に営み，その為胞体内構造は屡々不 明膫となつた，かかる恰ものたうち迴るが如き奇怪 な胞体㞄動は，やがて距くなり遂に静止してしまつ た.

この現象は巨核球の退行性変化が可成り進行した 
時期に認められた。

\section{8. 硝子様変性}

比較的少ない変性像であつたが，巨核球の固有顆 粒は胞体一部上り次第に不鮮明となり，遂には消失 し，それにつれて胞体の表面には光輝性の甚だ強い 不規則な岈譬が多数形成せられ，胞体全体が強く屈 光性を帯びて均質化し，無構造硝子様の外観を呈し てきた，人為的に高張食塭水の添加により，珈る 像を作り出す事が出来た。

\section{9. 蜂窩状変性}

胞体縁は一般に承滑で厚い胞体膜を有しているが， 内部は著しく污㨖となり，表面に $4 \sim 5 \mu$ 位の光輝 性の之しい压痕状の塞みを多数生じて，恰も蜂简状 を呈している．との窪みの間㭞を縫つて，光輝性の 強い大小不同の顆粓群乃至は索状帯を認めるが, 一 方核も光輝性の強い厚い核膜を有し明膫化認好られ た。

\section{0. 膜状伸展}

人の場合は比較的稀に見られたが，海犋ではさほ ど稀ではなかつた。

胞体は最初ヒトデ状の菲薄且つ尖鋭な偽足状突起 を出してくるか，固有運動は認められなかつた，伸 展は胞体全体に起り，遂には巨核球は膜状化して半 透明となり，固有顆粒は消失し，核は屡々濃縮に宿 つていた.

11. 細系形成

これは可成り高度の退行性湾化で，胞体縁より細 長い突起状物として通常 1 個乃至数個の突出を認内

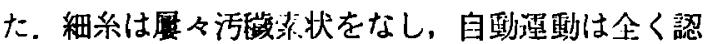
められず，長いものでは $200 \mu$ 以上に及んだ，そし てその先端部は一般に尖鋭且つ数個に断裂しており， 時に空胞の形成を見た．かかる細系は企く非可逆的 で，細系形成を認める巨核玨の胞体顆柆は粗粈化し， 歷々浱縮核を認めた。

12. ミエリン形成

巨核球では稀に認められる現象であつた。即ち巾 $0.3 \mu$ 前後の非常に細い系状物を胞体辺縁より数本 乃至十数本出し，てれらが盛んにブラウン運動を営 んでいるのを認めた，長さは不定だが通常20〜30 位いで，先端部に非常に小さな球状物を認めた，か かる現象は高張食壏水を添加した際に比校的上くみ られた。

13. 胞体赵化

巨核球胞体は容皘を增すとともに，全体として球 状非薄となり，周辺野より次第に固有顆柆の消失を
認め，胞体縁は屈光性にそしくなり，核も厚く同時 に膨化して胞体内に学上つたように見られた．膨化 が進むにつれて顆絃は漸次融解してゆき，遂には胞 体は無顆煜状となり，培地と殆ど同一屈光性をもつ た半透明水埂状を呈して胞体は著しく膨大し，最後 には胞体膜が破裂してしまうのが見られた。

かかる䔏化型は一般の培淘では見られず，低張培 地において屡々出現をみた。

14. 高度変性群

崩壊前段階において見られる非常に複雜な様相を 呈する一群の胞体变性像を総括して高度変性群とし た．これを更に大別して二つの型に分類した。 その

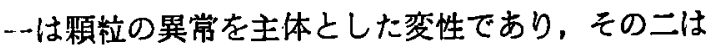
寗ろ顆柆の異常を余り認めず，胞体全体の菲薄化に よる桨性である。

併してれらは互に移行して複雑な変性像を呈する 場合も少なくなかつた。

\section{A. 粗精変性}

最初は顆柆異常を示しているが，漸次胞体構造は 充実感を失い粗糙化の傾向をとる様になる，そして 次第に胞体表面に凹凸起伏が現われ，その凸部や㟄 の部において顆柆の集合像がみられる様になつた。 他方胞体縁は徐心ながらも平猾さを失い不整となつ て来た。初期に比較的なだらかで規則正しかつた胞 体表面の凸回起伏は，時閒の経過とともに次第に著 明となり乱れて来た，それに伴つて顆柆の配列す不 規則となり，顆柆集合像も顕著となつて来た，又一 部顆接が消失して，その部に光煇性の强い小塊や索 状物を形成する事ああつた，胞体が益々粗精になる 之，その一部が次損して潰煬を形成したり，或は胞 体内容物か胞体縁より突出して，胞体は愈々不整污

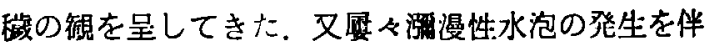
つたり，硝子様質の膨出をみた，尚，顆粒集合像が 著明となる一方，胞体が高度に粗糙化する為，顆粒 集合像が網状に連なり，網腿部が透過して見元，恰 あ著明な分野を形成しているが如き像を示す事すあ つた。

粗䊀变性に際しては，一般に港縮核を伴う事が多 く，咸壊は胞体縁より徐々に起るすのである。

B，菲薄変性

これは胞体企体が菲薄な観を呈し，光輝性にこし く，その内部に略々均等な光輝性の可成り強い固有 顆粒が規則正しく满漫性に配列し，薄暗い基質の上 に浮上つた様に鮮明に見られるのが特徵であつた。 胞体膜は屈光性に之しく，胞体周辺野程菲薄の锶加 
强く，胞体表面にはなだらかな起伏か見られ，一見 ビロード状を呈する。

核は概ね明瞭で，洤縮核の事が多かつた．胞体縁 は初期は略々平滑であつたが，後には次第に乱れ， 周辺部が膜状に伸展して崩壊するものが多く認めら れた。

第 2 第 骨榷巨核球の核の退行性変化につ いて

核の退行性変化は，胞体のそれと必ずしも平行せ ず，一般には核の変化が胞体の変化任先行し, 胞体 が軽度の変性像を示すに過ぎない時期に，核は既に 高度の変性に宿つている事が多かつた，核は健常な 巨核球にあつては，位相差影微鏡にてあ甚だ不明瞭 でその微練構造を明らかにする事が出来なかつた が，退行性変化が進行するにつれて次第比明膫とな つてきた。

核が明視されるに至る前段階として，最初は常胞 体との区別が不明膫であるが，全体として稍々薄暗 く雲絮状に喼められる。そして次第に核膜が屈光性 を帯びてくるに従つて，核の形状が渐く明らか上な つてくるが, 核の内部構造は尚不明膫であつた。 こ の時期までは，尚巨核球の渾動か認められた。

かかる変化に引続いて，核は種くの退行性変化に 陥つて行つた。

1. クロマチン塊形成

核の退行性変化の初期に見られるもので，光輝性 の强い大小不同の不正な小顆粒乃至索状物として認 められ，核内部に散在性に点在し，或は核膜内壁に 数個の塊となつて慮合しているのを䜑めた。

2. 核の光輝化

てれは最も后々遭遇した核変性像の一つである。 核膜か厚さを増すにつれて届光性が強くなり，次い で次第に核全体が光輝性を帯び，核網は消失して遂 には核全体が屈光珄の強い均等な無構造物と化し， 核容程が次第に減少するにつれて，核葉は球状乃至 卵円状を呈し，稍々硬い観を呈するに至つた。そし て核周囲には一層光輝性の強い量輪が認められた。

\section{3. 核浱縮}

最む普遍的住認められる変性像である.クロマチ ン結節の融合によりクロマチン構造は甚だ涱厚粗大 となつてくるー方，核は次第に容䖽を減して暗黒色 不整塊状を呈するに至るるのを云う。その過程で核 縁が明瞭で尚光輝性を有し，暗い核質内にクロマチ ン塊が散在して明るく輝き，㞓々顆粒状構造を示し， 核網がその間何弱く線状に輝いているのを認める事
があつた，核周囲の量輪は通常見られなかつた。

4. 核壊死

核濃縮が一層高度となつたもので，核容積は極度 に減少し, 最早数個の小暗黒色塊としてしか認めら れず，核構造は全く消失し，遂には融解消隇してゆ くのか認められた。

\section{5. 核葉融合}

てれは上述の諸型, 就中核镸縮と展々同時に認め られた。核葉融合は核の分葉数が培養の経過ととも に減じて行く事より明らかである.

併し糸状物により連慗せられている多核のむので は，個々の核葉は寧万退行性変化化伴い分踓独立の 傾向をとつた。然らざる環状乃至分萊の比較的少な い核にあつては，核葉の融合傾向が強かつた。

6. 核膨化

核は次第に容皘を增し，核葉は腸詰様になるが， それにつれて核内部す，初期にはクロ.マチン塊の散 在を認めるか，漸次朦朧化して，遂には軽度の浱谈 を見るに過ぎなくなる，核は胞体野に比し全体とし て屈光性がそしく，稍々薄暗く見られたか，核膜は 明瞭であつた。

7. 核水腫

低張培地中において認められた。核膨化の高度と なつたむので，核は容皘を著しく增し，個々の核葉 は球状に殸大し，又互に融合するのが見られた。次 いで寔々核は胞体の一側に押しやられるが，その部 の胞体に硝子様質の膨出が起り，遂にはこれが破れ， 核は胞体外押し出されるのを認めた。こうして培 地中に遊離された核は益々膨大し，核質は透明とな り，核内部には核葉の境が黒い線状物として見られ， 大小の残存クロマチン塊が散在して，透明化した核 梊之際立つた対照を示した。併し最後には核膜が破 れ，内容物の流出を見た。

\section{8. 核融解}

核融解像を一般培羡経過を追つてとらえる事は困 難であつたか，低張培地にて核膨化乃至核水腫の状 態より移行するのを目慗する事が出来た，かかる際 では, クロマチン融解が起り，核内部が均質化して くると，引続いて核膜の消失が起つてきた，即ち胞 体内の核に相当する部分は，一樣に薄暗色不透明の 辺縁不鮮明な，恰む胞体内に欠損部が生した如くに 認められ，次第にての欠損部の消失してゅくのが認 められた。

9. 核質分離

高度の変性に陥ると，核は光輝化し且つ浸縮して， 
分葉は類球状を呈し，或は融合して，その周囲を取 巻いて液体の眝溜を認める事が往々あつた。こして 液体中に浮游し盛んにブラウン運動を営む麾末の存 在を認める事ああつた。

10. 裸 核

時として培羑後 4 〜 日目顷に核を主体として胞 休野の僅かに存在する巨核球を認める事があつた。 かかる時㤥は寧ろ膨化の傾问をとつている場合が多 かつた. 又残存胞体は著しく荒廃し，胞体膜は最早 消失して，胞体緑は甚だしく污嵅不整状を呈してい た.

\section{第4章 総括並びに考按}

私は人並びに海俱骨铕の体外組織培羡を行い，骨 䯣巨核球の形態学的変化, 就中その退行性变化に就 いて，位相差顕微鏡を用いててれを観察した。そのの 結果巨核球が增生帯に出現してから崩填する迄には， 種ふなる退行性変化を示す事を知り，てれを次の如 くに分類した，即ち胞体の退行性変化については， 顆柆異常 · 分泌顆柆形成 · 空胞形成 - 水泡形成 - 球 状膨出 - 小舌状突起形成・泡沫形成 - 硝子様变性 蜂窩状変性・膜状伸展・細系形成・ エエリン形成・ 胞体膨化及び高度変性群（粗粩变性・菲薄変性）の 14型に分類した，又核の退行性変化に関しても，ク 口マチン塊形成・核の光輝化・核瀑縮・核壊死・核 葉融合・核膨化・核水腫・核融解・核蜇分雜及び裸 核の10型に分けた。

以上分類した各種変性像については，他の骨櫣細 胞の変性像と多くの点で類似点を有していた。

先ず胞体固有顆粒の変化に関しては，体外白血 球の退行性変化における顆粒の変化について, Barta48)，Philipsborn90)，片山(3)，平岡2930)等の 研究がみられるが，これらは要約するに，顆粒の配 列異常・膨大 ·融合・消失・変調染色性等について 断片的に述へられれたのに過ぎない，他方俞煘洰核 球(就いて, Seeliger(04)105), Frark61), Stern u. Hartmann 106)，Willi111)，Rohr96)96) 等の記載がみ られるか，てれらは主として特発性栓球減少性柴斑 病患者にみる淕抹染色標本上の巨核球顆粒の異常を 述へているに過ぎない. 即ち特発性栓球減少性柴环 病の場合には，健康人巨核球に見られるアズール顆 粒は殆ど認められないと Seeliger は述へており， Frark むこれを是認し, Stern u. Hartmann あ同 様の事を述べている，又 Willi はアズール顆粒の 久如の他に，アズール顆粒の配列の不規則な事を指
摘し，Rohr，位田4)，岩男3）等も同梀の事を記载し ている。

一方新鮮標本では，Dameshek 92）等が同様特発性 拴球減少性紫病の場合の巨核球を覾察し，成热乃 至移行型巨核球の約半数によく発達した颗柆形成か みられたが，顆粒の集合や所謂栓球単位の形成が られなかつたと速へ，更に退行性変化として，完全 な，或は部分的な顆粒の消失を認めている。併し， かかる静態観察上の所見は，私の意図している動態 観察に基つく形態学上の研究とは遥汃隔つたもの で，何等興味ある示㖫を与えてくれなかつた。

培盖下の巨核球の顆粒の変化は, その細胞粠造の 複雑さ之相俟つて，非常に錯綜している. その退行 性変化に際して，屡々顆粒の菓合傾向のみられるの は，他の骨敷細胞に比し甚だ特異的であり，ての為 恰む胞体内部において，栓球が形成せられつつある が如くに，多くの人々に推測されて来たのであろう. 又顆粒の光輝性の增加については，Izak 球の退行性変化の過程においててれを認めているが， 私は特にてれを初期変性徽候として強調したい。顆 柆の光輝性が増す事は, 明らかに胞体内に重大な変 化が起りつつある事を示している．緒方・三时村9) や平岡2930）等は白血球顆粒の変化は，てれのみを むつて退行性変化の基準とはなし難いと述へている が, 巨核球における顆粒の光輝性の増加は退行性変 化の進行を物語つていると考える.

巨核球の分泌顆粒の形成については，末だ系統的 観察乃至は細胞化学的研究を行つた人を知らない. 唯 Bessis 50 ) が脂肪性空胞の名称の下に，他の血液 細胞の同様の顆粒についての記载を行い，恐らく酸 素不足の結果発生するものであろうと推測している. 又 Zollinger 114 ) は細胞浮游液を $37^{\circ} \mathrm{C}$ 亿数㭙間保 つ㭙, 細胞内に光輝性を有する小顆煜の出現を認め, これを眝蔵顆柆と称して詳細な記述を行つている. かかる顆粒と，巨核球において私の認めた分泌顆柆 之は, 形態学的には殆ど同性質のあのと考える. 即 ち分泌顆粒は巨、核球に特有のあのではなく，培潇下 の血液細胞において，普遍的にその発生をみるもの であり，活溌に運動を営んでいる血液細胞にあ展々 認められる点や，その形態学的推移よりして，紐胞 内代謝産物之考えられる。

空胞形成は多くの細胞において認められ，乙れに 関しては，従来から種々の考察がなされて来た。体 外白血球関する研究で, Philipsborn90991) は個 の空胞は退行性変化の決定的な徴候であるとは云え 
ず、分必㙨能又は新陳代謝の産物の集皘場所とす考 えられるか，併し展々白血球障害の結果発生するむ のであると述へている。

又 Barta48) は, 空胞形成は細胞内に取入れられ た物澌の消化中に現われる二次的変化であつて，細 胞の機能六進を示啐するものと解釈した。

Arneth ${ }^{46)}$ 江空胞を退行性変化の現れと見做さ ず，細胞機能状態の一つの現れと考えた，一方，緒 方・三田村9）等は空胞を一般化細胞の被害状態の 現れと考え，小坂17)・片山(3) 西同様 細胞被障害現 象と見做し，又平岡20980）空胞を広義に解して退 行変性像として観察している. 水平38）吉細胞浮游 液の位相差镭察にて，空胞は一般に死にかかつてい る細胞の原形質内にみられると述へている。

更に Zollinger114）も空胞の出現を変性徽候と見 做しているが，Kosenow73）は空胞を有しながら活 溌な運動を示す白血球の存在する事より，少なくと あ最初は生体の防禦反応として現われるが，遂には 真の変性又は非可逆的退行過程に移行すると考えて あ不当でないと述へている，一方 Bessis50) は空胞 を5種類に分類し，収縮性空胞, Pinoeytosis によ る空胞, Potocy tsis による空胞, 脂肪性空胞及び核周 囲空胞を挙げ，その多くを細胞の変性像之結びつけ

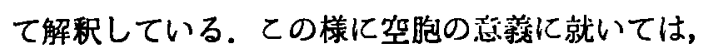
諸家により必ずしもこの見解が一致してない.

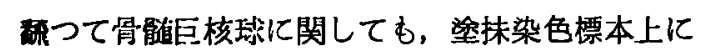
て. Barta49) - Willi111) - Rohr95)96) - 位田4) - 岩男3) 等の空胞化就いての記㦲をみるが, 病的時就中特発 生栓球減少性紫理病患者の巨核球们出現すると述へ ている以外に, 何等興味ある所見はみられない，新

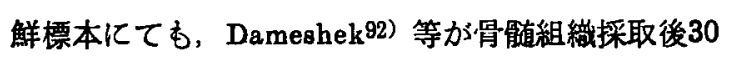
〜45分にして空胞形成を認め, 退行性变化の証拠を 示すあのと述へているに過ぎない.

私の行つた培羡実験では，少なくとも巨核球の空 胞の出来方には二様ある事を認めた. 即ち胞体表面 に接近して一時に多数の小空胞を形成する場合と， 胞体内部に散在性に小空胞を形成する場合とである。 前者は周囲の培液を吸収して出来ると云う I.$e w i 8^{800}$ の唱えた Pinocytosis によるものと思われるが，尚 その本態は明らかでい，併しかかる小空胞形成か， その初期において如何なる役割を演ずるにせよ，巨 核球の退行性変化の初まりである耕は問違いないと 思われる。これらの小空胞は, 引続きお互いに融合 或いは搪大して, 比较的急速に大小不同のいくつか の空胞にまで成長し，胞体を充たしてしまうむので，
空胞形成は常に非可逆的であつた。しかす不適当な 培卷条件により，出現巨核球の大多数が空胞形成を 示す事もあつた。

水泡形成む又浮游液中の細胞一般に見られる現象 で, 古くから Meltzor85) その他多くの研究者達に よつて述へられて来たか，近年 Zollinger114〉は細 胞㴔游液中での水泡形成を，位相差法により仔細に 観察している. 彼は多くの組織細胞か人工的培地中 におかれる時に，急速に細胞縁に発生する水泡状の 膨出について，Potocytosis と名付りて詳細な報告 を行っている. そしててれに就いては，人工的条件 下の細胞の液体摂取であろうと述へ，その発生には 細胞が生きていて液体中に浮游し，胞体膜を有して いなければならぬとし，場合によつては可逆的の変 化であると云つている. 又 Kosenow73) は血液細胞 においてあ Potocytosisは㞓々現れるが，ての出現 は恐らく細胞の障害を意味しているのであろうと述 へている. 更に稻垣2は，水泡形成は透作用によ り紐胞の水分交換に役立ち，誘圧調節意義ある あのであろうと推測している。

私の培羡実験では，Potocytosis に該当すると思 われる局在型の水泡形成は，巨核球では此较的稀に しか認められず，しかも旔全な巨核球においては見 られず，退行性変化の稍々進んだ時期に認められる 事より，病的な状態において発生するすのと考える。 丵漫型及び多発型水泡形成は細胞機能の高度の荒廃 に基つく，胞体獏の渗透圧調節の失調に依るのでは ないかと思われる。

球状膨出については，胞体膜の一部に減弱部位が 出米て，そてから胞体内压の上昇に伴つて，主とし て胞体基镇が瘤として突出したものと考える．その 為略々同大の胞体が並び，恰も細胞分裂を起してい るかの如き観を呈する事があるが，明らか仙両者の 構造上の差が認められる点より篮別出来る.

小舌状突起形成については，Bessis50) が初めて 新鮮標本にて詳細な観察を行い，かかる現象は骨榷 巨核球に或程度特異的であり，恐らく栓球分離を示 腹するむのであろうと推測したもので，後に彼はそ の誤りなる事を認め，乙れは自家融解の結果発生し， 栓球分離之は無関係であると述へている．私は，か かる現象は巨核球の胞体膜の或種の障害により発生. するむのて，一種の変性像と考えている.

泡溗形成についても，小婜状突起形成上同様の事 が云えるが，一厒高度の障害に際してみられ，その 状態は恰む細胞断末魔の死戦を思わせた。 
膜状伸展は他の骨韧道細胞や栓球においても認めら れる事があるが，巨核球においては運動とは全く無 関係な現象である。

細系形成は白血球等では展々認められ，Bessis 50 ) は細胞が運動経過中に後に残した胞体の能動的伸展 を意味していると述べているが，私が巨核球におい て認めたものは，てれとは全く異質的なもので，運 動之無関係である事は勿論, 可成り高度の変性過程 においてみられた。胞体より突出した空胞が破裂し て，その後に残された残存空胞膜により形成される のではないかと思われるが，その間の関係や成立の 要因については尚疑問がある.

ミエリン形成に関しては，Bessis50) 亿依れば， Auer (1933). Furchgott (1940) 等多くの研究诸 によつて研究されて来たもので，最も檿々鹪害され た赤血球表面より発生するが，又白血球や栓球加ら あ生ずるむので，リポイド含有量の多い細胞成分が 異常な分離様式をとる，極くありふれた現象である

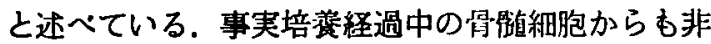
常に屡々その発生を認めたが，一般に運動静止後に みられるもので，首ろ変性過程の現象と思われた． 骨哩道巨核球においては稀に見られたが，その形態は 他の骨蹃細胞にみられるすのと全く同じであつた。

巨核球の高度变珄群に関しては，従来全くその記 载をみない所で，他の骨髄紐胞に見られない複雑且 つ特異な梯相を呈するものである．蓋し何を以つて 細胞の死と断定するかは，甚だ困難な問題であり， Zollinger114）は核の変化を以つて細胞死の徽侯と見 做しているが，胞体の変化のみによつて細胞の死を 論ずる事は至難であろう。

かかる見地から，私は細胞の崩壊前段階として， 特に高度変性群の一項を設けて記载し分類を試みた。

次に核の退行性変化では，先ず核の光輝化に就い てみるに，てれは従来の梁抹染色慓本上の锶察では 賽い知る事の出来ない，in vitroにおける特異な 核の変化である．Zollinger は細胞浮游液中での細 胞形䖩の変化の研究で, 自然に，又はホルマリン・ アルコール等の添加や加熱に上つて，核が光輝性を 帯びてくる事を認め，乙れを光烟型と名付けて細胞 死を脰味するものと解している．私の観察した核光 輝化之. Zollinger の称する光輝型之は，略心闬了一 の状態を指すものである，光輝化像は㫦髄巨核球に

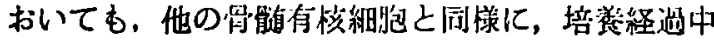
最も展々遭遇し且つ核の明膫化後比洨的早期化認め られる事が多く，核浱縮や核融解等は通常核の光輝
化に遅れて出現をみている．かかる核の光輝化を以 つて，直ちに練胞の死之断定出来るか否かは双置き， てれが核の重篤な変性を意味する事は間違いないと 考えら机る。

次にクロマチン塊形成・核濐縮・罗死そして臌化・ 水䭪・融解等の変化については，一般細㿣において も展々認められる周知の現象であり，骨䯣巨核球に 何等特異的なものではないので，こてでは唯巨核球 においてむ同様の現象が認められるという事実の記 载に止的る。

核葉瀜合については，最近 Bessis 等により，そ の記载をみるが，昔の学者が保存血の研究にて，数 日すると多核白血球が変形して骨髄球になると述へ ているのは，核の変性現象の結果起つた核葉融合を 詔つて解釈したものである，骨髄巨核球においても 分葉核が培羑の経過とともに融合して，恰も凹凸を 有する一核の如くに誤認される事があり，注意を要 する問題と思う。

最後に裸核に関しては，従来胃准途抹染色標本に おいてむ尿々認められ，種々の問題を提起している. 併し一般には骨䯣巨核球より旺盛な栓球分踓が行わ れた後の核の残骸であるとの主張が受入れられてい る. 即与 Willi(11) - Rohr96)96) ・ 位田4) - Schenker ${ }^{101)}$ 等は裸核を栓球形成後に残留した濃縮核であると見 做し，栓球形成の六進に基くあのと考えている。 天 野1)はこれを是認しながらも，尚粱抹染色慓本作成 途次の人工的産物ではないかと疑念を抱いている. 滰川24）は位田の主張に替同し，栓球を作つた後の 牫䯓之考えられるか，一方再生不良性坌血患者にて も裸核の多い所より，乙の場合は寜ろ!核球の变性 像之解すべきかむ知れぬと述へている，私の行つた

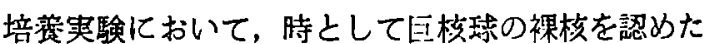
が，乙の場合は明らかに巨核球の退行变性像であり， 胞体が崩壊し去つた痕跡を同時化認めている．かか る現泉のみから，裸核の本態を推論する事は危険か む知れないが，本実験を通して，ての問題を眺める 時，裸核を栓核分離と結びつけて考える在来の主張 には大いに疑問がある。

\section{第 5 章 結 論}

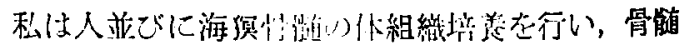

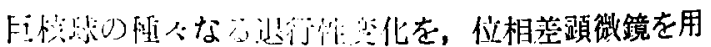
いて钼察し，次の絬詅を待た。

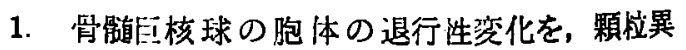
常 - 分泌顆柆形成 - 空胞形成 - 水泡形成 - 球状腰 
出・ 小舌状突起形成・泡沫形成・硝子椂変性 - 蜂窩 状変性・膜状伸展・細系形成・ミエリン形成・胞体 膨化・高度変性群（粗徙变性・菲薄変性）の14型侣 分類した.

2. 骨髄巨核球の核の退行性変化を, クロマチン 塊形成・核の光輝化 - 核港縮 - 榜壊死 - 核葉融合 核膨化・核水腫・核融解・核質分㪬及び裸核の10型 に分類した。

3. 巨核球退行性変化の初期徵侯は胞体固有顆粒 の異常, 就中その光輝性の増加である.

4. 空胞形成は最も展々遭遇する巨核球の退行性 変化である.

5. 核の光輝化は最も多く見られる核の変性像の
一つで，㞗々核鋠縮や融解に先行して出現し；核の 重篤な障害を物語つている。

撋筆するに当り䅂始御琶篤なる御指導と御校閲を 賜わつた恩師承木教授並びて角南檴皈に深甚なる謝 意を表します。

(本論文の要旨的 1 回アシア国際血液学会飞括 いて発表した)。

（文 献 後 掲）

\section{写真 説 明}

写真 1. 顆粒異常を示す骨榷巨核球 (人)約 $1000 \times$

写真 2. 分泌顆粒を形成せる骨髓巨核球 (人) 約 $1000 \times$

写真 3. 分泌顆粒を形成せる骨艏巨.核球（海撔）約 $1000 \times$

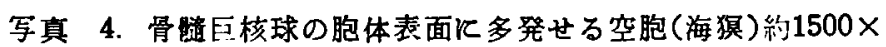

写真 5. 胞体内部飞未いて空胞を形成せる骨随巨核球 (人)約 $1500 \times$

写真 6. 巨卡大な空胞を形成せる骨胵巨核球(人)約 $1500 \times$

写真 7. 核周团空胞形成古示高䯣巨核球 (人) 約 $1500 \times$

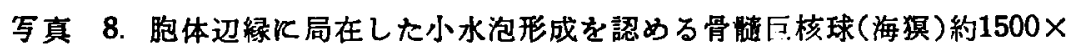

写真 9. 胞体表面任多発せる水泡を示す骨䯈巨核球(海㩧)約 $1500 \times$

写真 10. 巨大なな水泡を形成した骨鰱巨核球(海犋)。胞体内容物が水泡内飞移行しているのを認める。約 $1000 \times$

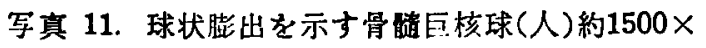

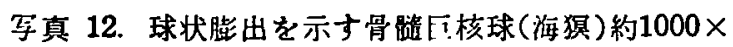

写真 13. 小舌状突起形成を営む骨随巨核球(人)約 $1500 \times$

写真 14. 泡沫形成を示す骨髓巨兵核球(海㩧)約 $1000 \times$

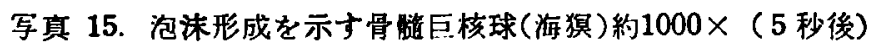

写真 16. 泡沫形成を示す骨随巨核球(海犋) 的 $1000 \times$ (10秒後)

写真 17. 骨随巨核球の硝子様変性(人)約 $1500 \times$

写真 18. 骨解巨核球の蜂䆛状变性(人)約 $1000 \times$

写真 19. 膜状伸展を示寸骨瞌巨核球(海撔)約 $600 \times$

写真 20. 細系形成を示す骨粗巨核球(人)約 $1500 \times$

写真 21. 胞体㜆化をるる骨醚巨核球(人)約 $1500 \times$

写真 22. 骨随巨核球の粗㯧変性(人)約 $1500 x$

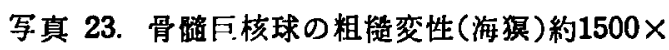

写真 24. 骨路巨核球の菲薄変性(人)約 $1500 \times$

写真 25. 骨粕巨核球の核のクロマチン塊形成(人)約 $1000 \times$

写真 26. 核の光淿化を示す骨随巨核球(人)約 $1500 \times$

写真 27. 骨鱕巨核球の核漲縮 (人) 約 $1500 \times$

写真 28. 骨随巨核球の核壊死(人)約 $1500 \times$ 


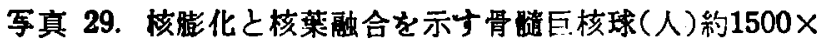

写真 30. 骨髉巨核球の核融解(人)約 $1500 \times$

写真 31. 骨链巨核球の核質分離(人)約 $1500 \times$

写真 32、骨䯣巨核球の裸核(海犋)約 $1500 \times$

\title{
Studies on Megakaryocytes by Means of Bone-Marrow Tissue Culture
}

\section{Part 1. Various Degenerative Changes of Megakaryocytes in Human and Guinea Pigs}

\author{
By \\ Kenjiro Ogawara \\ Department of Internal Medicine Okayama University Medical School \\ (Director : Prof. Kiyoshi Hiraki)
}

In bone-marrow tissue cultures of human and guinea pigs the author carried out observations on various degenerative changes of megakaryocytes with a phase-contrast microscope, and obtained the following results :

1. The degenerative changes in the cytoplasm of megakaryocytes are classified into 14 types; namely, granule abnormality, secretion granule formation, vacuole formation, bleb formation, spherical protrusion, small tongue-like processes, bubble formation, hyalin degeneration, honeycomb degeneration, membranous extension, thread formation, myelin formation, the swelling of the cytoplasm, and advanced degenerative group (coarse and uniform degenerations).

2. The degenerative changes in the nucleus of megakaryocytes are calssified into 10 types; namely, chromatin mass formation, brilliant nucleus, pyknosis, nuclear necrosis, nuclear lobe fusion, nuclear swelling, nuclear edema, caryolysis, dissociation of nuclear sustances, and naked nucleus.

3. The early symptoms of degenerative changes in megakaryocytes are abnormalities of the specific granules in cytoplasm, especially the increase in the brilliancy.

4. The vacuole formation is one of the degenerative changes most frequently encountered in megakaryocytes.

5. The brilliancy of the nculeus is one of the nuclear degenerative changes most frequently observable as well, and it often precedes the pyknosis and caryolysis, indicating the severity of nuclear disturbnaces. 


\section{大河原論文附図}
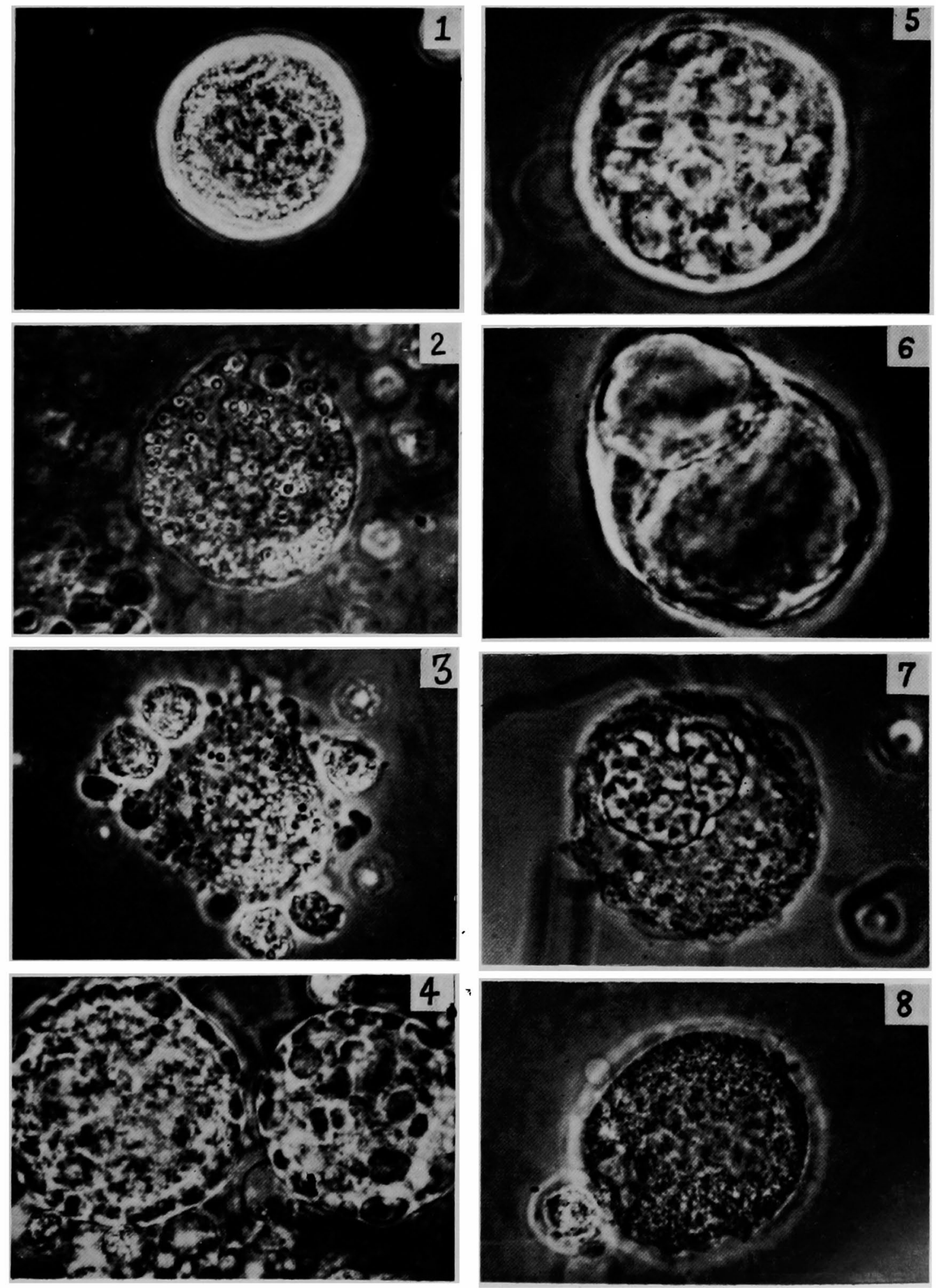
大河原論文附図
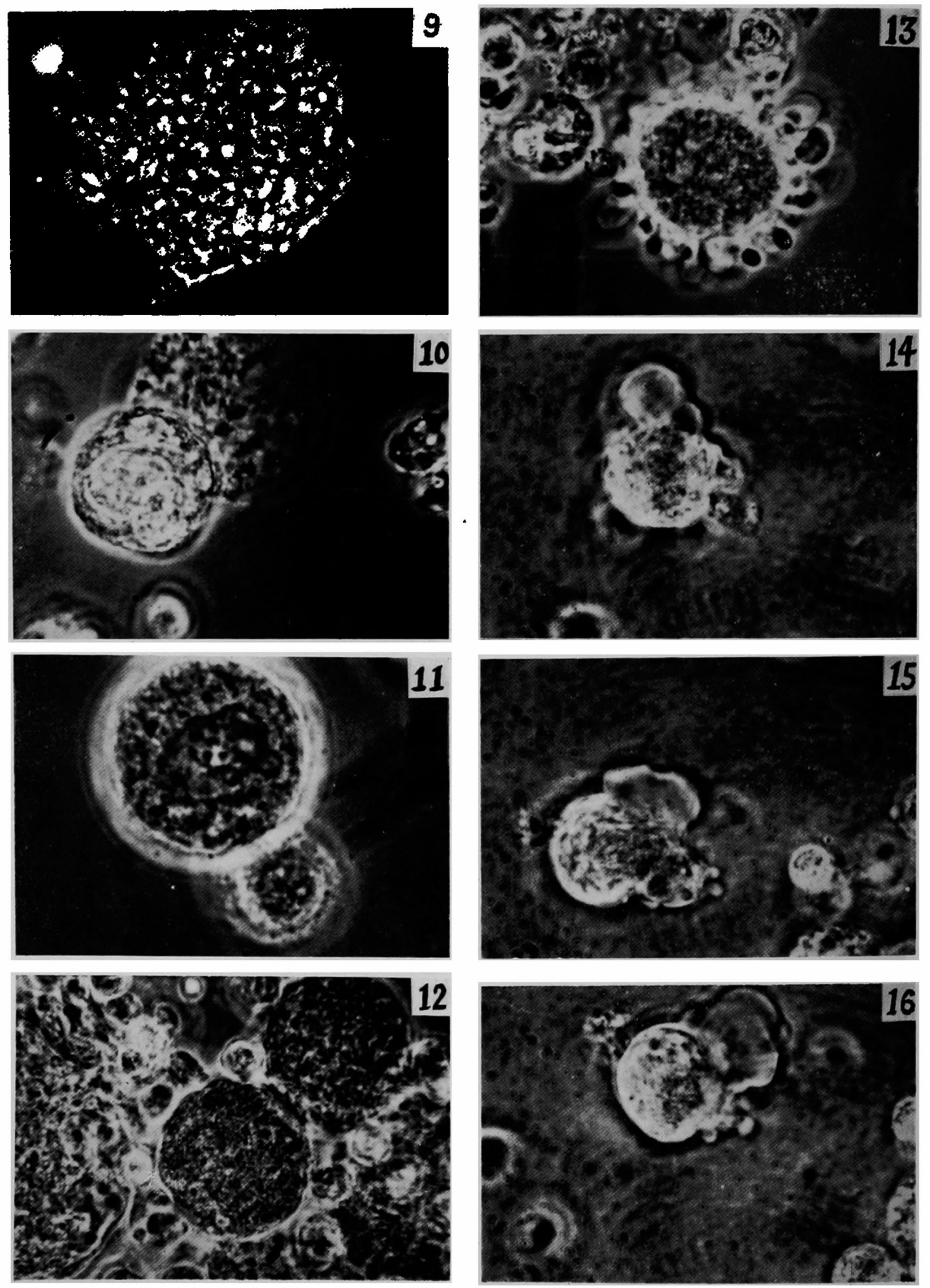


\section{大河原論 文 附 図}
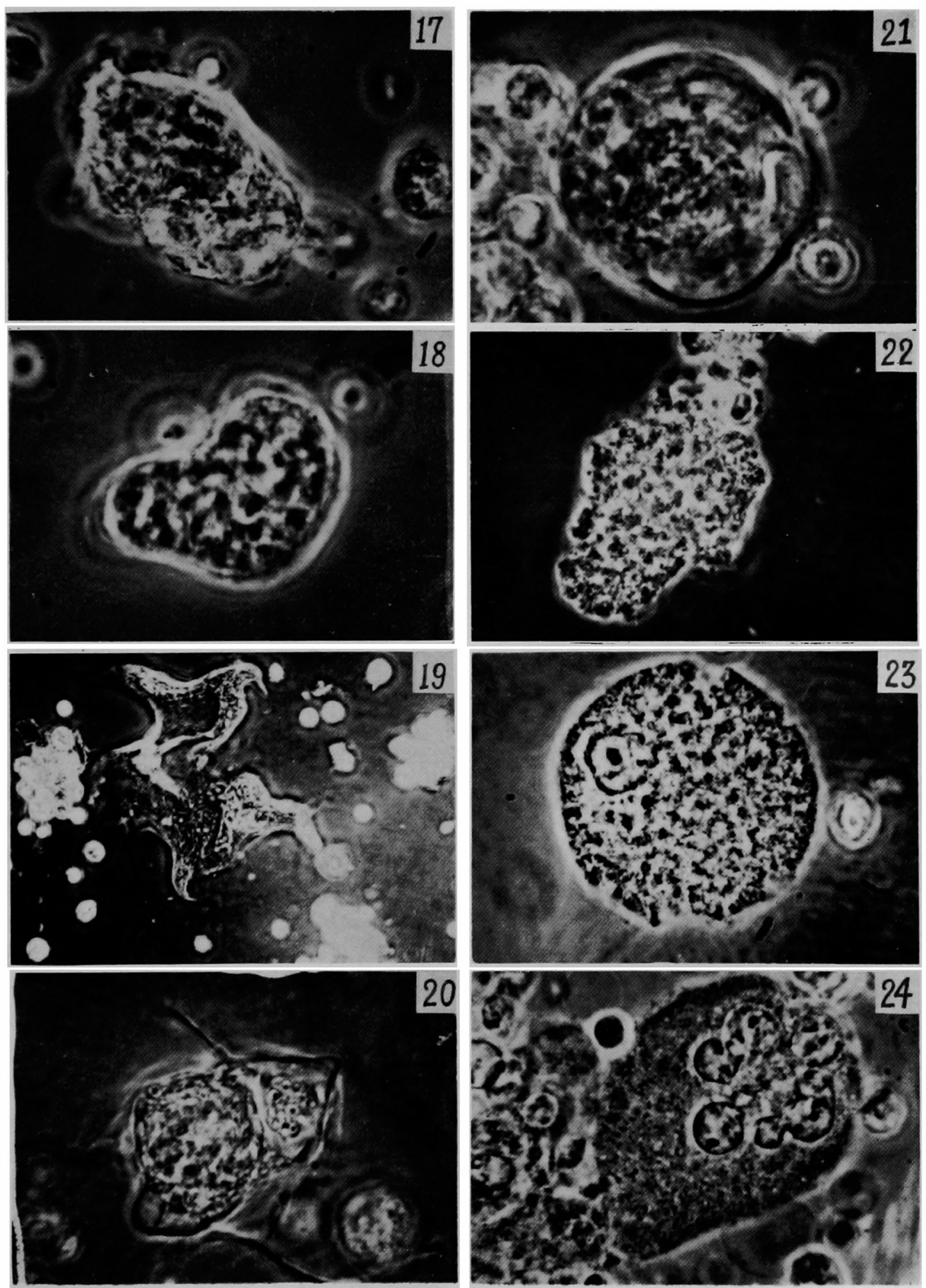
大河原論文附図
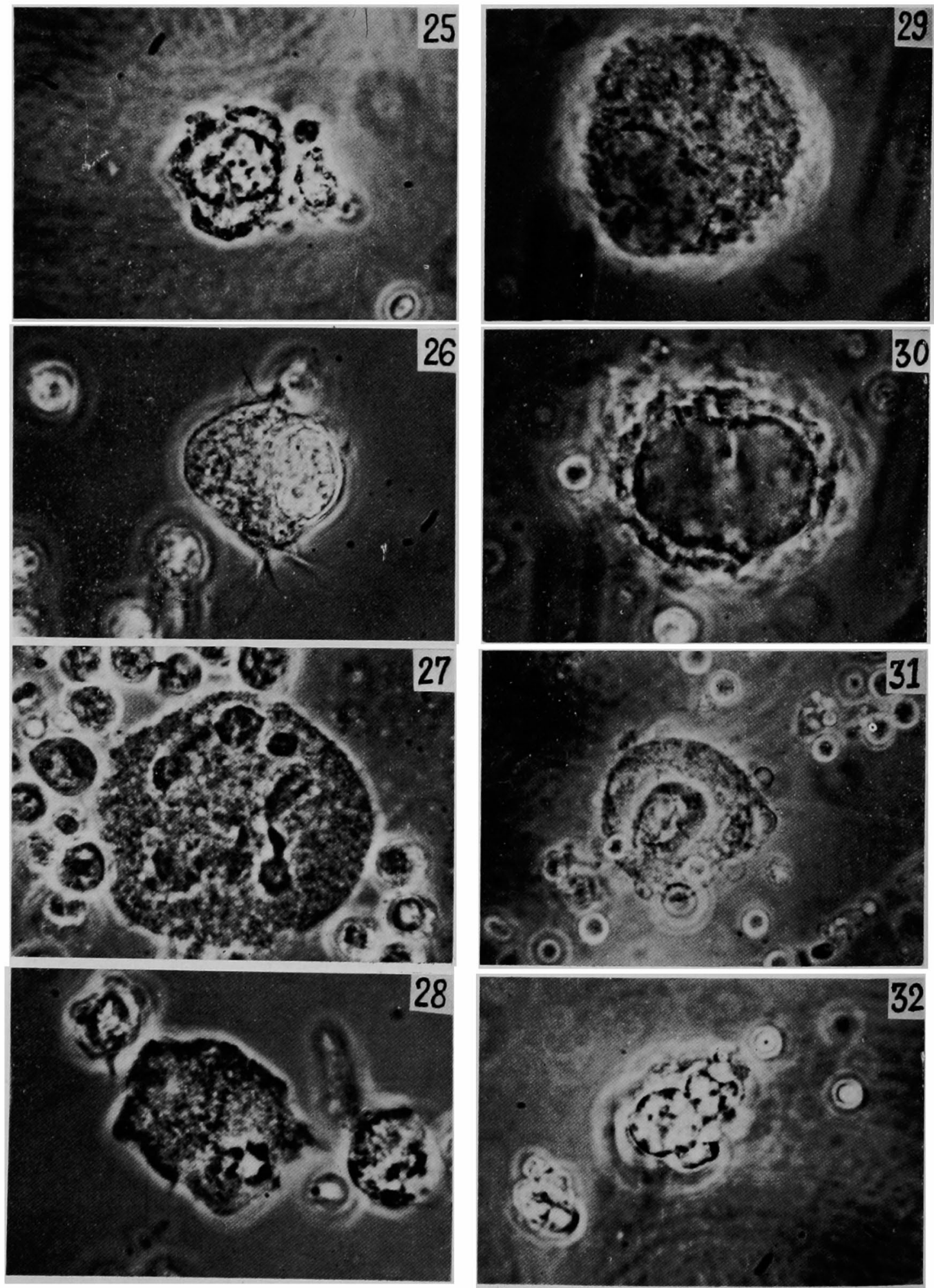